\title{
The Law of One Price of Central European Countries - Analysis of Feed Barley
}

\author{
P. Bubáková
}

Faculty of Economics and Management, Czech University of Life Sciences Prague, Czech Republic

\begin{abstract}
Anotace
Článek se zabývá platností zákona jedné ceny na mezinárodním trhu krmného ječmene v rámci vybraných středoevropských zemí, jmenovitě České republiky, Německa, Rakouska, Slovenska, Polska a Mad'arska. K analýze jsou využity měsíční ceny od června 1995 do prosince 2012. Kointegrace cen je zkoumána pro jednotlivé páry zemí. Platnost zákona jedné ceny je ověřena na základě testování modelu vektorové korekce chyby. Výsledky poukazují na platnost zákona jedné ceny pro většinu zkoumaných zemí. U všech párů s výjimkou Slovenska byla nalezena kointegrace. U kointegrovaných párů byl zákon jedné ceny potvrzen u 8 z 10 párů na $5 \%$ hladině významnosti. Dominantním trhem na zkoumaném mezinárodním trhu je Německo, které jednosměrně určuje ceny ostatních zemí. Rakousko zaujímá pozici druhého dominantního trhu. Země původní Visegrádské čtyřky, konkrétně Česká republika, Polsko a Mad'arsko jsou charakteristické vzájemnou provázaností cen.
\end{abstract}

\section{Klíčová slova}

Zákon jedné ceny, ječmen, evropské země, Johansenův test, model vektorové korekce chyby, cenová provázanost.

\begin{abstract}
The paper examines the validity of the Law of One Price (LOP) in the international market for feed barley among selected Central European markets, namely the Czech Republic, Germany, Austria, Slovakia, Poland and Hungary. Monthly prices over the period June 1995 to December 2012 are used. Each country pair is tested for cointegration, and the hypothesis of LOP is tested in the Vector Error Correction model. The results show that the LOP holds for the majority of markets. Cointegration was confirmed among all pairs of countries except for pairs with Slovakia. For cointegrated country pairs, the LOP holds for 8 out of 10 pairs at a $5 \%$ level of significance. Germany has a dominant position within the investigated international trade and determines the prices of other countries. Austria is the second most dominant market. Countries of the original Visegrad group, namely the Czech Republic, Poland and Hungary, are characterized by simultaneous price relationships.
\end{abstract}

\section{Key words}

Law of One Price, barley, European countries, Johansen test, Vector Error Correction model, price interdependence.

\section{Introduction}

Prices and price policy are significant factors which determine the functioning of the market. The level of prices leads to the allocation of resources and interconnects markets horizontally and vertically. The horizontal point of view is focused on price transmission among spatially separated markets, such as different countries, where the Law of One Price is being analysed. From an international point of view, the Law of One Price (LOP) is an economic law which states that, after adjustment for transaction and transportation costs, an identical good from two countries must have the same price when the prices are expressed in the same currency (Biondo, 2010, Holman, 2011, Vavra and Goodwin, 2005). The identical price of a good in separated markets appears as a result of arbitrage. A trader buys the product in the market with the lower price and sells it in the market with the higher price, and profits from the temporary difference. As a result of this behaviour, the demand for the particular good grows in the cheaper market, and consequently the price increases 
as well. Conversely, the price in the second market is pushed down, which leads to price convergence until the point where the prices are equal. If prices are not entirely equal, it is a sign of barriers on the international market (Holman, 2007).

Studies focused on Law of One Price analysis can be classified into two main groups. The first group investigates the law in aggregated markets such as different countries. Publications belonging to this group include Vataja (2000), Spreen, Kilmer and Pitta (2007), and Bakucs et al. (2012). The second group analysed the LOP at the desegregated level which includes, for example, the analysis of price relations within one country but in several territorial markets, such as regions or cities. Among publications from this field we can mention authors such as Ahmadi-Esfahani (2006), Syrovátka (2010), Iregui and Otero (2011), and Bubáková (2012).

Ahmadi-Esfahani (2006) showed that the LOP does not hold in most Chinese wholesale food markets. The author analysed food markets in Beijing, Nanjing, Shanghai, and Shenzhen during the period 1993 to 1999 using a cointegration approach. Syrovátka (2010) analysed the price interactions between the Czech and world wheat markets over the period 1995 to 2010 . The results of cointegration analysis showed that there is no long-run relationship between Czech and world wheat prices. Following analysis of short-term dynamics suggested that Czech prices are affected from $50 \%$ by world prices and from another $50 \%$ by other factors. Iregui and Otero (2011) examined 54 food products in 13 major Columbian cities. Based on the panel data set, the results show that the LOP is valid for most products, and market integration is more common for cities or markets with similar population and economic size. Bubáková (2012) explored empirically the validity of the LOP among regions of the Czech Republic over the period 2002 to 2008 . The study was focused on pork prices. Time series with a two-week data period frequency and a cointegration approach were used. The estimations suggested that the LOP is valid in the investigated regions. Vataja (2000) analysed the LOP of 10 commodity groups in the international market, namely lead, maize, newsprint, rice, rubber, sugar, tin, wheat, wool, and zinc. The LOP was confirmed for 14 cases out of 17 examined bilateral trades. Moreover, the estimations suggested that a full two-thirds of the deviations from the long-run relationship are eliminated within one year. Spreen, Kilmer and Pitta (2007) demonstrated the importance of product homogeneity for LOP testing. As an example, authors discussed the homogeneity issue for fruits and vegetables. These commodities have additional packing costs, such as heavier boxes or chemical treatments, for international markets in comparison with the domestic market. These additional costs are reflected in the final price in the international market and cause price differences in LOP studies. Authors confirmed the existence of this problem by analysing the FOB prices of fresh grapefruits for markets in Florida, Japan, the European Union and Canada. Bakucs et al. (2012) focused on crop markets, analysing the relationships of wheat prices between Germany and Hungary. According to the results, the LOP holds for only $27 \%$ of observations in a five-year period.

Among most recent publications we can mention authors such as Smutka, et. al (2013) or Lajdová and Bielik (2015). Smutka, et. al (2013) analysed the relationships between $\mathrm{Czech}$ food prices and prices of global and EU market. Results show that Czech food market reacts sensitively to changes in food prices. The examination was performed over the period 2006-2012. Authors also highlight the rise in food prices over the last decade. Lajdová and Bielik (2015) examined dairy sector and its prices in Slovakia. They analysed cointegration of milk prices, however they focused more on asymmetric reactions among prices and shown an existence of imperfect market structure.

\section{Materials and methods}

Time series of the agricultural prices of feed barley (variable Pbarley) were used for analysis. The investigated markets are: the Czech Republic (CZ), Germany (DE), Austria (AT), Slovakia (SK), Poland (PL) and Hungary (HU). Particular markets are labelled by stated shortcuts, e.g. the variable PbarleyDE is the agriculture price of barley in Germany. The time series of prices have a monthly frequency and cover the period from July 1995 to December 2012 (210 observations). Prices are expressed in the same units, namely in EUR/100 kg. The analysis began in July 1995 because of the unavailability of Austrian prices before this date. The data were obtained from the statistical offices of particular countries (see in source of Figure 1). The time series of prices have been seasonally adjusted because of the presence of statistically significant seasonality at a $5 \%$ level of significance. The time series used for analysis can be seen in Figure 1.

Analysis of the LOP is used for each pair 
of examined countries and contains the following steps.

The first step is to test the non-stationarity of the time series. The order integration, I(d), is determined using the Augmented Dickey-Fuller (ADF) test, from the authors Dickey and Fuller (1979), PhillipsPerron (PP) test (1988) and Kwiatkowski-PhilipsSchmidt-Shin (KPSS) test (1992). Specification of a test, i.e. whether to use a constant and trend, is determined based on its statistical significance. The optimal lags of the ADF and PP tests were chosen based on automatic selection of a Schwarz information criterion (1978).

If the time series are not stationary and have the same order of integration, cointegration is evaluated according to the Johansen test (1988 and 1991). The lag for the cointegration test is based on information criteria such as the Schwarz (SIC) (1978), Akaike (AIC) (1974) and Hannan-Quinn (H-Q) (1979) information criterion. Vector Autoregressive (VAR) models with lags determined by these information criteria are estimated. Then, the final lag is determined based on the best results of autocorrelation testing of the VAR model with a particular lag. When the optimal lag has been determined, the cointegration is analysed and Vector Error Correction (VEC) models are estimated. Several specifications of the VEC model are considered. Specifications differ with regard to the presence of constants and trends in the short-run and long-run relationships. Three fundamental specifications are used in the analysis (see in Table 1). Type 1 considers a constant in the long-run relationship, which reflects the value
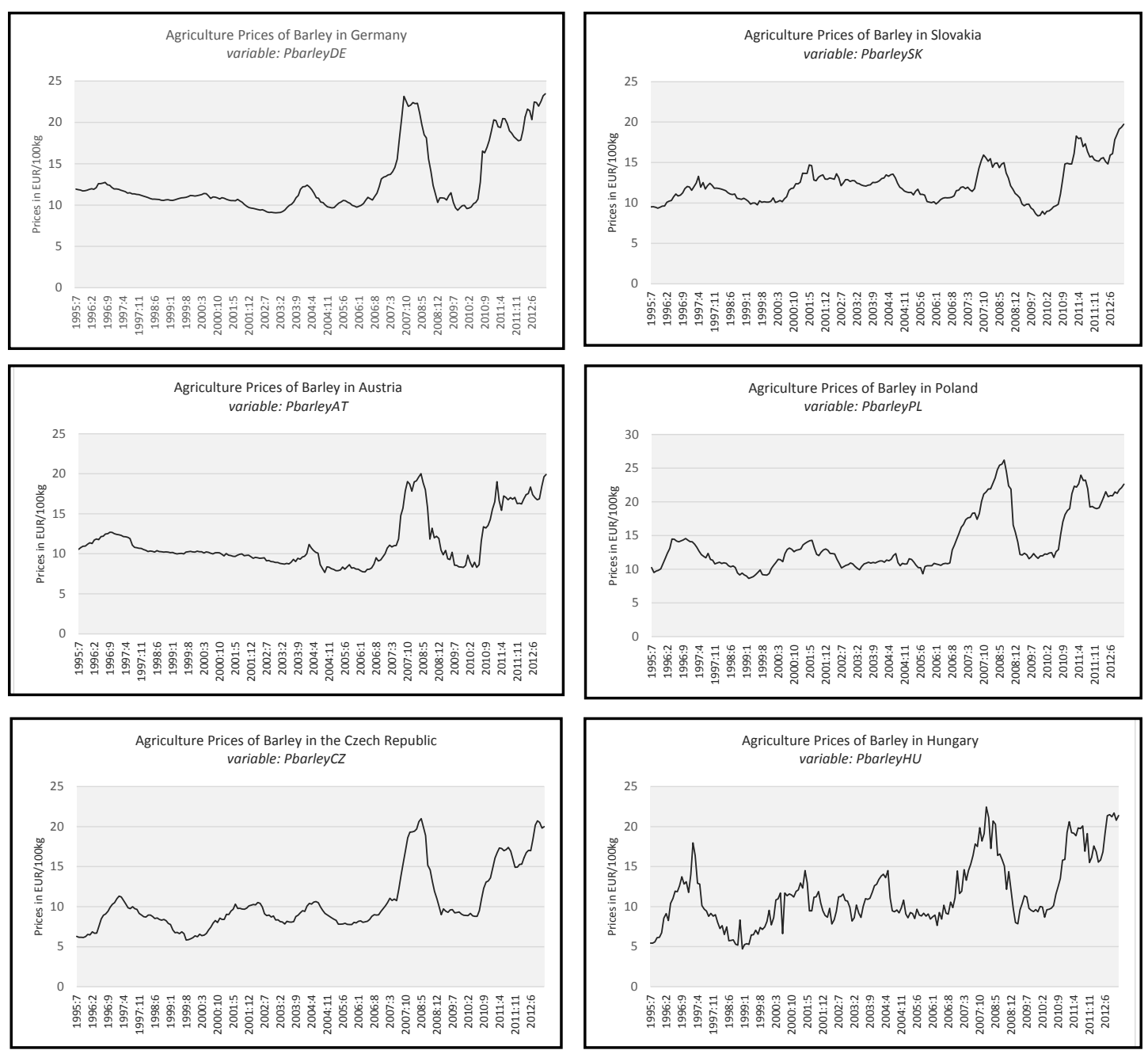

Source: Český statistický úřad, Štatistický úrad Slovenskej republiky, Glowny Urzad Statystyczny, Statistischer Monatsbericht, BMELV and Statisches Bundesamt, Statistical Database of Statistics Austria, Központi Statisztikai Hivatal

Figure 1: Prices of feed barley in selected countries, units EUR/100 kg; period 1995:07 to 2012:12. 
of transaction costs between prices. Type 2 contains a constant in the long-run relationship as well as in short-run relationships. Type 3 has a trend in the long-run relationship which allows for a change in transaction costs over time.

If cointegration exists among several VEC models for one country pair, the best model is chosen according to the LR test. After selection of the best specification of the VEC model, the LOP is evaluated based on hypotheses testing. Consider now just two countries, where one is the exporting country with price Pit and the other is the importing country with price Pjt. In this case, only one cointegration vector can exist and, for example, with respect to the Type 5 VEC model, this vector can be expressed by the equation:

$\alpha\left[P_{j t}+\mu+\delta t+\gamma_{1} P_{i t}\right]$

where $\alpha$ is the error correction factor, $t$ is a deterministic trend with parameter $\delta, \mu$ is a constant of the cointegration vector, and the parameter $\gamma$, represents the relationships between prices $P_{j t}$ and $P_{i t}$. The Law of One Price is evaluated based on testing of cointegration vector (1), namely:

$$
\begin{aligned}
& H_{0}: \gamma_{1}=-1 \\
& H_{1}: \gamma_{1} \neq-1
\end{aligned} .
$$

If the parameter $\gamma_{1}$ is equal to -1 in the cointegration vector, the Law of One Price is confirmed and the long-run relationship can be expressed by:

$$
\alpha\left[P_{j t}+\mu+\delta t-1 P_{i t}\right]
$$

Cointegration vector (3) can be rewritten as a relationship:

$$
P_{j t}=-\mu-\delta t+1 P_{i t},
$$

which expresses the exact dependency of price in the importing country on price in the exporting country and, of course, dependency on transaction costs expressed by the estimated part $(-\mu-\delta t)$.

The LR test is used to verify hypotheses (2). The type of cointegration vector (i.e. whether the vector contains a constant and trend) is determined in the previous step.

For the analysis and estimates, EViews, version 4, was used.

\section{Results and discussion}

First of all, the order of integration for a particular time series must be determined. Three test were performed, namely the ADF, PP and KPSS tests. The results of integration order testing are shown in Table 2. Test statistics are evaluated at a $5 \%$ level of significance.

According to the performed tests, the time series are non-stationary and integrated of the order I(1) for barley prices in the Czech Republic, Slovakia, Poland, Austria and Hungary at a $5 \%$ level of significance. The KPSS test suggests an order of integration equal to $I(2)$ only in the case of German prices. However, based on other tests such as ADF and PP we can conclude that the time series is I(1), like the prices of other countries.

Since the time series of prices are non-stationary and integrated of the same order, we can test the cointegration. The long-run relationship is analysed between each pair of countries. As a first step, an adequate number of lags was selected. For the number of lags used in the cointegration test, see Appendix A1. A summarization of the cointegration test results is shown in Tables 3, 4 and 5. Table 3 contains the results of pairs for which cointegration was confirmed in just

\begin{tabular}{|l|c|c|c|c|c|}
\hline \multirow{2}{*}{$\begin{array}{l}\text { VEC model } \\
\text { type }\end{array}$} & \multicolumn{2}{|c|}{ Long-run relationship } & \multicolumn{2}{|c|}{ Short-run relationship } & \multirow{2}{*}{ VEC model specification } \\
\cline { 2 - 5 } & constant & trend & constant & trend & \multirow{2}{*}{$\Delta Y_{t}=\alpha \cdot\left[\mathrm{B} Y_{t-1}+\mu\right]+\sum_{s=1}^{S} \Gamma_{s} \Delta Y_{t-s}+u_{t}$} \\
\hline Type 1 & YES & NO & NO & NO & \multirow{2}{*}{$\Delta Y_{t}=\alpha \cdot\left[\mathrm{B} Y_{t-1}+\mu\right]+c+\sum_{s=1}^{S} \Gamma_{s} \Delta Y_{t-s}+u_{t}$} \\
\hline Type 2 & YES & NO & YES & NO & $\Delta$ \\
\hline Type 3 & YES & YES & YES & NO & $\Delta Y_{t}=\alpha \cdot\left[\mathrm{B} Y_{t-1}+\mu+\delta \cdot t\right]+c+\sum_{s=1}^{S} \Gamma_{s} \Delta Y_{t-s}+u_{t}$ \\
\hline
\end{tabular}

Source: own elaboration based on Charemza and Deadman (1997)

Table 1: Specifications of VEC models for cointegration testing. 


\begin{tabular}{|c|c|c|c|c|c|c|c|}
\hline TEST & Data & Type 1) & Test. stat. & $\begin{array}{l}\text { Critical } \\
\text { value }\end{array}$ & P-value & Reject $\mathrm{H}_{0}$ & Conclus \\
\hline & \multicolumn{7}{|c|}{ PbarleyCZ } \\
\hline \multirow{2}{*}{ ADF } & Original & C & -3.14 & -3.432 & 0.0999 & NO & \multirow{2}{*}{$\mathbf{I}(\mathbf{1})$} \\
\hline & Diferences & A & -7.437 & -1.942 & 0.0000 & YES & \\
\hline \multirow{2}{*}{ PP } & Original & B & -1.52 & -2.875 & 0.5168 & NO & \multirow{2}{*}{ I(1) } \\
\hline & Diferences & A & -7.385 & -1.942 & 0.0000 & YES & \\
\hline \multirow{2}{*}{ KPSS } & Original & C & 4.007 & 0.146 & $\mathrm{x}$ & YES & \multirow{2}{*}{ I(1) } \\
\hline & Diferences & B & 0.372 & 0.463 & $\mathrm{x}$ & NO & \\
\hline & \multicolumn{7}{|c|}{ PbarleySK } \\
\hline \multirow{2}{*}{ ADF } & Original & B & -1.049 & -3.432 & 0.7355 & NO & \multirow{2}{*}{ I(1) } \\
\hline & Diferences & A & -11.002 & -1.942 & 0.0000 & YES & \\
\hline \multirow{2}{*}{$\mathbf{P P}$} & Original & B & -1.376 & -2.875 & 0.5935 & NO & \multirow{2}{*}{ I(1) } \\
\hline & Diferences & A & -11.239 & -1.942 & 0.0000 & YES & \\
\hline \multirow{2}{*}{ KPSS } & Original & C & 6.904 & 0.146 & $\mathrm{x}$ & YES & \multirow{2}{*}{ I(1) } \\
\hline & Diferences & B & 0.254 & 0.463 & $\mathrm{x}$ & NO & \\
\hline & \multicolumn{7}{|c|}{ PbarleyPL } \\
\hline \multirow{2}{*}{ ADF } & Original & C & -3.419 & -3.432 & 0.0517 & NO & \multirow{2}{*}{ I(1) } \\
\hline & Diferences & A & -6.456 & -1.942 & 0.0000 & YES & \\
\hline \multirow{2}{*}{ PP } & Original & B & -1.682 & -2.8752 & 0.4387 & NO & \multirow{2}{*}{ I(1) } \\
\hline & Diferences & A & -9.932 & -1.942 & 0.0000 & YES & \\
\hline \multirow{2}{*}{ KPSS } & Original & C & 4.051 & 0.146 & $\mathrm{x}$ & YES & \multirow{2}{*}{ I(1) } \\
\hline & Diferences & B & 0.276 & 0.463 & $\mathrm{x}$ & NO & \\
\hline
\end{tabular}

\begin{tabular}{|c|c|c|c|c|c|c|c|}
\hline TEST & Data & Type 1) & $\begin{array}{l}\text { Test. } \\
\text { stat. }\end{array}$ & $\begin{array}{l}\text { Critical } \\
\text { value }\end{array}$ & P-value & $\begin{array}{c}\text { Reject } \\
\text { H0 }\end{array}$ & Conclus \\
\hline & \multicolumn{7}{|c|}{ PbarleyDE } \\
\hline \multirow{2}{*}{ ADF } & Original & C & -2.144 & -3.432 & 0.5181 & NO & \multirow{2}{*}{$\mathbf{I}(1)$} \\
\hline & Diferences & A & -8.146 & -1.942 & 0.0000 & YES & \\
\hline \multirow{2}{*}{ PP } & Original & C & -2.164 & -3.432 & 0.5068 & NO & \multirow{2}{*}{ I(1) } \\
\hline & Diferences & A & -8.427 & -1.942 & 0.0000 & YES & \\
\hline \multirow{2}{*}{ KPSS } & Original & C & 13.385 & 0.146 & $\mathrm{x}$ & YES & \multirow{2}{*}{ I(2) } \\
\hline & Diferences & B & 0.554 & 0.463 & $\mathrm{x}$ & YES & \\
\hline & \multicolumn{7}{|c|}{ PbarleyAT } \\
\hline \multirow{2}{*}{ ADF } & Original & C & -1.623 & -3.432 & 0.7807 & NO & \multirow{2}{*}{ I(1) } \\
\hline & Diferences & A & -11.942 & -1.942 & 0.0000 & YES & \\
\hline \multirow{2}{*}{ PP } & Original & C & -1.732 & -3.431 & 0.7337 & NO & \multirow{2}{*}{ I(1) } \\
\hline & Diferences & A & -12.051 & -1.942 & 0.0000 & YES & \\
\hline \multirow{2}{*}{ KPSS } & Original & C & 22.564 & 0.146 & $\mathrm{x}$ & YES & \multirow{2}{*}{ I(1) } \\
\hline & Diferences & B & 0.247 & 0.463 & $\mathrm{x}$ & NO & \\
\hline & \multicolumn{7}{|c|}{ PbarleyHU } \\
\hline \multirow{2}{*}{ ADF } & Original & $\mathrm{C}$ & -3.0467 & -3.432 & 0.1222 & NO & \multirow{2}{*}{ I(1) } \\
\hline & Diferences & A & -17.009 & -1.942 & 0.0000 & YES & \\
\hline \multirow{2}{*}{ PP } & Original & C & -3.115 & -3.432 & 0.1055 & NO & \multirow{2}{*}{ I(1) } \\
\hline & Diferences & A & -16.952 & -1.942 & 0.0000 & YES & \\
\hline \multirow{2}{*}{ KPSS } & Original & C & 3.643 & 0.146 & $\mathrm{x}$ & YES & \multirow{2}{*}{ I(1) } \\
\hline & Diferences & B & 0.043 & 0.463 & $\mathrm{x}$ & NO & \\
\hline
\end{tabular}

Note: $\mathrm{CZ}=$ Czech Republic, $\mathrm{SK}=$ Slovakia, $\mathrm{PL}=$ Poland, $\mathrm{DE}=$ Germany, $\mathrm{AT}=$ Austria, HU = Hungary

ADF test, PP test: H0: non-stationarity, KPSS test: H0: stationarity

1) Type A, B and C refer the specification of the test, i.e. Type A: model without constant and trend, Type B: model with the constant, Type C: model with constant and trend

Source: own calculations, EViews, ver. 7

Table 2: Results of the ADF, PP and KPSS unit root tests.

\begin{tabular}{|l|cc|cc|cc|cc|}
\hline Country pair & \multicolumn{2}{|c|}{ CZ, PL } & \multicolumn{2}{c|}{ CZ, DE } & \multicolumn{2}{c|}{ CZ, AT } & \multicolumn{2}{c|}{ PL, AT } \\
\hline Number of cointeg. vectors: & Trace stat. & P-value & Trace stat. & P-value & Trace stat. & P-value & Trace stat. & P-value \\
None & 26.107 & 0.007 & 22.924 & 0.021 & 26.948 & 0.037 & 29.565 & 0.017 \\
At most 1 & 7.959 & 0.084 & 4.597 & 0.331 & 7.315 & 0.313 & 12.507 & 0.0502 \\
\hline Result & \multicolumn{2}{|c|}{ cointegration vector } & \multicolumn{2}{c|}{ cointegration vector } & 1 cointegration vector & \multicolumn{2}{c|}{1 cointegration vector } \\
Model specification & \multicolumn{2}{|c|}{ Type 1 } & \multicolumn{2}{c|}{ Type 1 } & \multicolumn{2}{c|}{ Type 3 } & \multicolumn{2}{c|}{ Type 3 } \\
\hline
\end{tabular}

Note: evaluation at a $5 \%$ level of significance

Source: own calculations, EViews 7

Table 3: Results of the Johansen cointegration test; cointegration confirmed for one model specification.

one specification of the VEC model. Table 4 shows the pairs for which more specifications of the VEC model led to a cointegrated vector. Finally, Table 5 reflects countries for which cointegration was not found with any model specification. Tables 3 and 4 show the final results; however, all types of the VEC model have been tested, and overall results for these countries are attached in Appendix A2.

Cointegration was confirmed among all pairs of countries except for pairs with Slovakia. In the case of Slovakian prices, the Trace statistic leads to the null order of the matrix $\Pi$ for each pair, and thus modelling of these relationships would be a spurious regression.
The VEC model with a constant in the long-run relationship (i.e. Type 1) will be used for the country pairs Czech Republic-Poland and Czech RepublicGermany. The price relationship between pairs Czech Republic-Austria and Poland-Austria will be examined based on the model with a constant and trend in the long-run relationship and a constant in the short-run relationship (Type 3). Testing of the cointegration of prices for other pairs of countries also led to confirmation of a long-run relationship; however, more types of VEC model are suitable for modelling (see in Table 5). One specification of the VEC model should be used for final LOP testing. The decision concerning which type of VEC model is best is based on the LR 


\begin{tabular}{|c|c|c|c|c|c|c|c|c|}
\hline \multirow{2}{*}{$\frac{\text { Country pair }}{\text { Number of cointeg. vectors: }}$} & \multicolumn{4}{|c|}{$\mathrm{CZ}, \mathrm{HU}$} & \multicolumn{4}{|c|}{ PL, DE } \\
\hline & $\begin{array}{l}\text { Trace } \\
\text { stat. }\end{array}$ & P-value & $\begin{array}{l}\text { Trace } \\
\text { stat. }\end{array}$ & P-value & $\begin{array}{l}\text { Trace } \\
\text { stat. }\end{array}$ & P-value & $\begin{array}{l}\text { Trace } \\
\text { stat. }\end{array}$ & $\mathrm{P}$-value \\
\hline None & 26.122 & 0.007 & 32.141 & 0.007 & 29.348 & 0.002 & 36.078 & 0.002 \\
\hline At most 1 & 6.531 & 0.154 & 12.323 & 0.054 & 4.591 & 0.331 & 10.306 & 0.114 \\
\hline Result & \multirow{2}{*}{\multicolumn{2}{|c|}{$\begin{array}{c}1 \text { cointeg. vector } \\
\text { Type } 1\end{array}$}} & \multirow{2}{*}{\multicolumn{2}{|c|}{$\begin{array}{c}1 \text { cointeg. vector } \\
\text { Type } 3\end{array}$}} & \multirow{2}{*}{\multicolumn{2}{|c|}{$\begin{array}{c}1 \text { cointeg. vector } \\
\text { Type } 1\end{array}$}} & \multirow{2}{*}{\multicolumn{2}{|c|}{$\begin{array}{c}1 \text { cointeg. vector } \\
\text { Type } 3\end{array}$}} \\
\hline Model specification & & & & & & & & \\
\hline Country pair & \multicolumn{4}{|c|}{ PL, HU } & \multicolumn{4}{|c|}{ DE, HU } \\
\hline Number of cointeg. vectors: & $\begin{array}{l}\text { Trace } \\
\text { stat. }\end{array}$ & P-value & $\begin{array}{l}\text { Trace } \\
\text { stat. }\end{array}$ & P-value & $\begin{array}{l}\text { Trace } \\
\text { stat. }\end{array}$ & P-value & $\begin{array}{l}\text { Trace } \\
\text { stat. }\end{array}$ & P-value \\
\hline None & 25.248 & 0.009 & 31.261 & 0.01 & 20.623 & 0.045 & 26.508 & 0.042 \\
\hline At most 1 & 6.296 & 0.169 & 11.83 & 0.065 & 5.127 & 0.270 & 10.949 & 0.090 \\
\hline Result & \multirow{2}{*}{\multicolumn{2}{|c|}{$\begin{array}{l}1 \text { cointeg. vector } \\
\text { Type } 1\end{array}$}} & \multirow{2}{*}{\multicolumn{2}{|c|}{$\begin{array}{c}1 \text { cointeg. vector } \\
\text { Type } 3\end{array}$}} & \multirow{2}{*}{\multicolumn{2}{|c|}{$\begin{array}{c}1 \text { cointeg. vector } \\
\text { Type } 1\end{array}$}} & \multirow{2}{*}{\multicolumn{2}{|c|}{$\begin{array}{c}1 \text { cointeg. vector } \\
\text { Type } 3\end{array}$}} \\
\hline Model specification & & & & & & & & \\
\hline Country pair & \multicolumn{6}{|c|}{ DE, AT } & & \\
\hline Number of cointeg. vectors: & $\begin{array}{l}\text { Trace } \\
\text { stat. }\end{array}$ & P-value & $\begin{array}{l}\text { Trace } \\
\text { stat. }\end{array}$ & $\mathrm{P}$-value & $\begin{array}{l}\text { Trace } \\
\text { stat. }\end{array}$ & P-value & & \\
\hline None & 31.914 & 0.001 & 31.384 & 0.000 & 47.489 & 0.000 & & \\
\hline At most 1 & 3.208 & 0.543 & 2.792 & 0.095 & 6.679 & 0.379 & & \\
\hline Result & \multirow{2}{*}{\multicolumn{2}{|c|}{$\begin{array}{l}1 \text { cointeg. vector } \\
\text { Type } 1\end{array}$}} & \multirow{2}{*}{\multicolumn{2}{|c|}{$\begin{array}{c}1 \text { cointeg. vector } \\
\text { Type } 2\end{array}$}} & \multirow{2}{*}{\multicolumn{2}{|c|}{$\begin{array}{c}1 \text { cointeg. vector } \\
\text { Type } 3\end{array}$}} & & \\
\hline Model specification & & & & & & & & \\
\hline Country pair & \multicolumn{6}{|c|}{ AT, HU } & & \\
\hline Number of cointeg. vectors: & $\begin{array}{l}\text { Trace } \\
\text { stat. }\end{array}$ & P-value & $\begin{array}{l}\text { Trace } \\
\text { stat. }\end{array}$ & P-value & $\begin{array}{l}\text { Trace } \\
\text { stat. }\end{array}$ & P-value & & \\
\hline None & 21.275 & 0.036 & 20.397 & 0.008 & 26.158 & 0.046 & & \\
\hline At most 1 & 1.67 & 0.842 & 0.875 & 0.349 & 3.7 & 0.785 & & \\
\hline Result & 1 coin & vector & 1 coin & vector & 1 coin & vector & & \\
\hline Model specification & & & & & & & & \\
\hline
\end{tabular}

Note: evaluation at a $5 \%$ level of significance

Source: own calculations, EViews 7

Table 4: Results of the Johansen cointegration test; cointegration confirmed for more model specifications.

test. The LR test compares whether the restricted version with a smaller number of parameters is better than the unrestricted wider version. The results of LR tests and selection of a final model for LOP testing is shown in Table 6 . The procedure starts with the most general version of the VEC model and continues to the more specific versions, until the best model is found.

As we can see in Table 6, model of Type 3 with constants and trend will be used only for pair Germany-Austria. Type 3 is also used for pairs Poland-Austria and Czech Republic-Austria as was stated in Table 4. For other pairs, the most suitable model is specification with only the constant in the long-run relationship. Adequate specification of models are used to test the hypothesis of the LOP. The results of LR tests for this part are placed in Table 7 . The LOP is evaluated at a $5 \%$ and $1 \%$ level of significance.
The LOP holds for the majority of country pairs. The LOP was rejected only between the Czech Republic and Austria and between Germany and Austria, at a $5 \%$ level of significance. However, if we consider a $1 \%$ level of significance, i.e. we need more evidence to reject the validity of the LOP, the null hypothesis cannot be rejected and the LOP is valid. The results suggest that the market for feed barley is highly integrated. Only in two cases of country pairs, the prices are not exactly equal over the long term, but are very close to each other.

The estimation of the VEC model was used not just for LOP hypothesis testing but also for evaluation of the price direction between countries, i.e. the power of markets. We can use the error correction factor $\alpha$ and test whether this parameter is statistically significant in particular equations. If error correction factor $\alpha$ is 


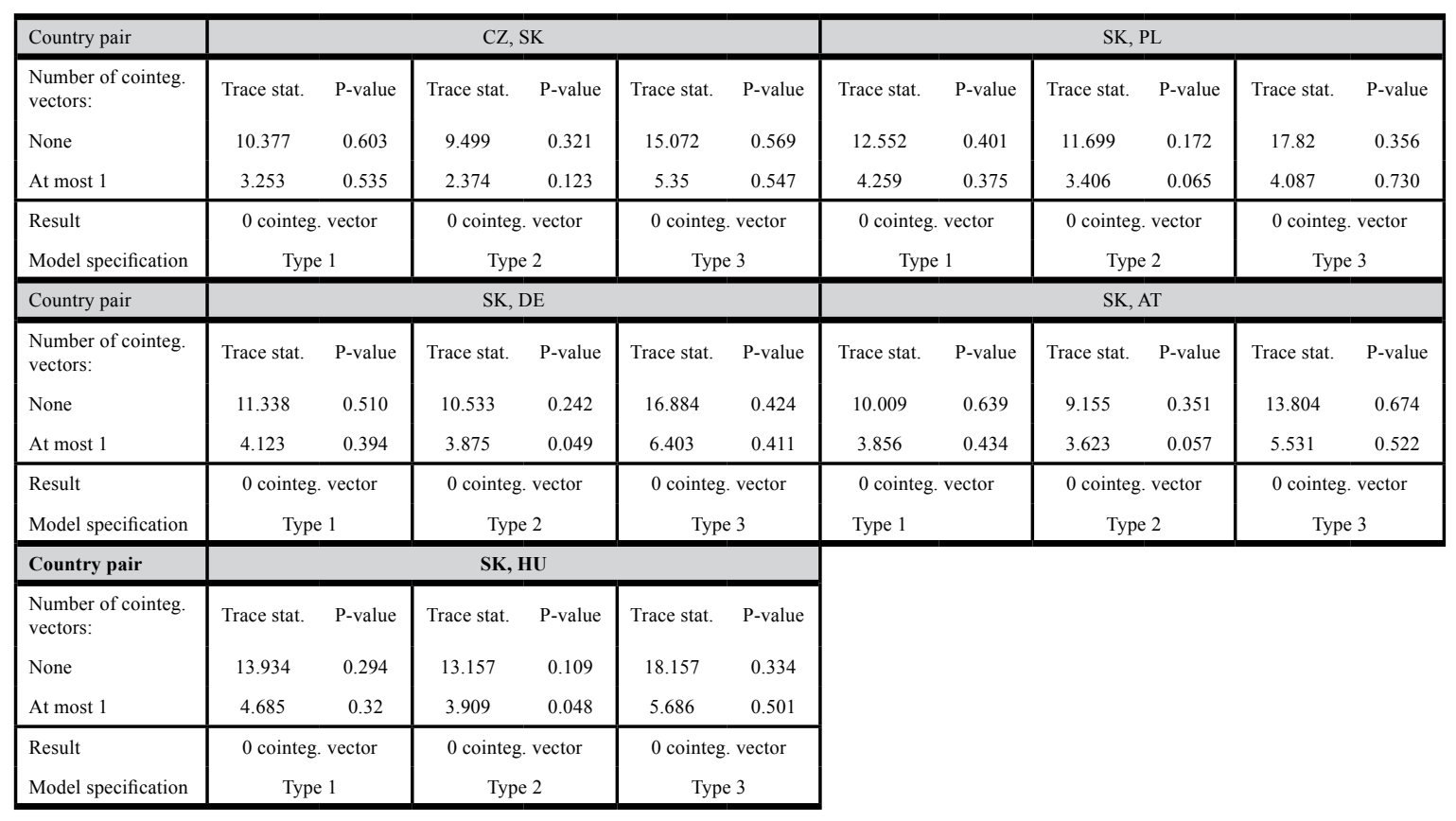

Note: evaluation at a $5 \%$ level of significance

Source: own calculations, EViews 7

Table 5: Results of the Johansen cointegration test; cointegration not confirmed.

\begin{tabular}{|c|c|c|c|c|c|c|c|c|}
\hline Country Pair & $\begin{array}{c}\text { Types of VEC } \\
\text { model }\end{array}$ & $\begin{array}{c}\text { Log-lik. } \\
\text { unres. } \\
\text { ver. }\end{array}$ & $\begin{array}{c}\text { Log-lik. } \\
\text { restr. } \\
\text { ver. }\end{array}$ & LR stat & (p) & $\begin{array}{c}\text { Critical } \\
\text { val. } \boldsymbol{\chi}^{\mathbf{2}} \\
\boldsymbol{\alpha}=\mathbf{0 . 0 5}\end{array}$ & Evaluation & Conclusion \\
\hline $\mathbf{C Z}, \mathbf{H U}$ & Type. 3 vs. Type 1 & -475.964 & -476.378 & $\mathbf{0 . 8 2 6 8}$ & 3 & 7.81473 & Not reject $\mathbf{H}_{\mathbf{0}}$ & Type $\mathbf{1}$ \\
\hline $\mathbf{P L}, \mathbf{D E}$ & Type. 3 vs. Type 1 & -337.681 & -338.406 & $\mathbf{1 . 4 5}$ & 3 & 7.81473 & Not reject $\mathbf{H}_{\mathbf{0}}$ & Type $\mathbf{1}$ \\
\hline PL, HU & Type. 3 vs. Type 1 & -555.074 & -555.568 & $\mathbf{0 . 9 8 6 4}$ & 3 & 7.81473 & Not reject $\mathbf{H}_{\mathbf{0}}$ & Type $\mathbf{1}$ \\
\hline DE, $\mathbf{A T}$ & Type. 3 vs. Type 2 & -330.297 & -336.405 & $\mathbf{1 2 . 2 1 7 2}$ & 1 & 3.84146 & Reject $\mathbf{H}_{\mathbf{0}}$ & Type $\mathbf{3}$ \\
\hline DE, $\mathbf{H U}$ & var. 4 vs. var. 2 & -507.002 & -507.319 & $\mathbf{0 . 6 3 4 2}$ & 3 & 7.81473 & Not reject $\mathbf{H}_{\mathbf{0}}$ & Type $\mathbf{1}$ \\
\hline \multirow{2}{*}{ AT, $\mathbf{H U}$} & Type. 3 vs. Type 2 & -572.909 & -574.378 & $\mathbf{2 . 9 3 7 4}$ & 1 & 3.84146 & Not reject $\mathbf{H}_{\mathbf{0}}$ & Type $\mathbf{2}$ \\
\cline { 2 - 9 } & Type 2 vs. Type 1 & -574.378 & -574.775 & $\mathbf{0 . 7 9 4 4}$ & 2 & 5.99146 & Not reject $\mathbf{H}_{\mathbf{0}}$ & Type $\mathbf{1}$ \\
\hline
\end{tabular}

Note: For pair DE and AT, the comparison between Type 2 and 1 was not consider, because wider specification was determined as the most suitable

Source: own calculations, EViews 7

Table 6: Selection of the final model for LOP testing for countries in Table 4.

statistically significant, for example in the equation $\triangle$ PbarleyCZ$_{t}=\alpha\left(\right.$ PbarleyCZ $Z_{t-1}-1$ PbarleyDE $t_{t-1}$ $+1.99)$, then the long-run relationship affects prices in the Czech Republic, and thus the Czech market is influenced by German prices. The particular $\alpha$ is referred to as $\alpha_{\text {PbarleyCZ}}$, because it belongs to the equation of Czech prices. Then, we evaluate the statistical significance of the second equation of the particular VEC model. In this example it is $\triangle$ PbarleyDE $=\alpha_{\text {PbarleyDE }}$ (PbarleyCZ $Z_{t-1}-$ $1 P$ barleyDE $\left.E_{t-1}+1.99\right)$. If the ${ }_{\alpha \mathrm{PbarleyDE}}$ is statistically significant, then prices in Germany are affected by the long-run relationship and thus both markets are simultaneously dependent. However, if the $\alpha_{\text {PbarlevDE }}$ is not statistically significant, the effect of the long-run relationship is zero and German barley prices are unaffected by Czech prices over the long term. In such a case the German market is exogenous and is unaffected by Czech prices, i.e. only a one-sided effect exists, namely Germany is the dominant market which determines the price level. The estimated long-run relationships of the VEC model and $\alpha$ testing are summarized in Tables 8 and 9 . Table 8 contains country pairs for which the LOP was confirmed; Table 9 shows results for country pairs for which the LOP was rejected at a $5 \%$ level of significance. The one-sided and simultaneous 


\begin{tabular}{|c|c|c|c|c|c|}
\hline Country Pair & Log-lik. unres. ver. & Log-lik. restr. ver. & LR stat & Evaluation 1) & Conclusion \\
\hline CZ, PL & -288.706 & -290.538 & $\mathbf{3 . 6 6 4}$ & No reject $\mathrm{H}_{0}$ & LOP valid \\
\hline CZ, DE & -266.39 & -266.458 & $\mathbf{0 . 1 3 6 4}$ & No reject $\mathrm{H}_{0}$ & LOP valid \\
\hline \multirow{2}{*}{ CZ, AT } & -292.365 & -295.171 & $\mathbf{5 . 6 1 1 6}$ & Reject $\mathrm{H}_{0}$ at $5 \%$ & LOP rejected \\
\cline { 5 - 6 } & & & & No reject $\mathrm{H}_{0}$ at $1 \%$ & LOP valid \\
\hline CZ, HU & -476.378 & -476.394 & $\mathbf{0 . 0 3 2 8}$ & No reject $\mathrm{H}_{0}$ & LOP valid \\
\hline PL, DE & -338.406 & -339.515 & $\mathbf{2 . 2 1 6 8}$ & No reject $\mathrm{H}_{0}$ & LOP valid \\
\hline PL, AT & -368.051 & -368.418 & $\mathbf{0 . 7 3 4 6}$ & No reject $\mathrm{H}_{0}$ & LOP valid \\
\hline PL, HU & -555.568 & -555.786 & $\mathbf{0 . 4 3 6 8}$ & No reject $\mathrm{H}_{0}$ & LOP valid \\
\hline \multirow{2}{*}{ DE, AT } & -330.297 & -332.408 & $\mathbf{4 . 2 2 2 0}$ & Reject $\mathrm{H}_{0}$ at $5 \%$ & LOP rejected \\
\cline { 5 - 6 } & & & No reject $\mathrm{H}_{0}$ at $1 \%$ & LOP valid \\
\hline DE, HU & -507.319 & -507.513 & $\mathbf{0 . 3 8 9}$ & No reject $\mathrm{H}_{0}$ & LOP valid \\
\hline AT, HU & -574.775 & -575.296 & $\mathbf{1 . 0 4 2 2}$ & No reject $\mathrm{H}_{0}$ & LOP valid \\
\hline
\end{tabular}

Note: For pair DE and AT, the comparison between Type 2 and 1 was not consider, because wider specification was determined as the most suitable

Source: own calculations, EViews 7

Table 7: Results of the Law of One Price testing for country pairs.

effects are already distinguished in the tables.

As we can see, simultaneous effects appear in the case of the Czech market with the Polish, Hungarian and Austrian markets and also between Poland and Hungary. Other country pairs have a dominant market, i.e. in general, country A affects prices of country $\mathrm{B}$, however country $\mathrm{B}$ is not able to affect prices in country A. The dominant markets from these pairs are Germany and Austria.

The constant in the long-run relationship captured the effect of transaction costs. Table 9 shows the results of unrestricted versions of the VEC models, which are better than restricted versions. The estimated parameters of prices show the final effect of price changes. In particular, in the case of German and Austrian prices, an increase in feed barley prices in Germany by 1 EUR $/ 100 \mathrm{~kg}$ leads to an increase in prices in Austria by 0.906 EUR $/ 100 \mathrm{~kg}$. The estimated parameter is very close to the number one. In the case of Austrian and Czech prices, an increase in the Czech prices of feed barley by $1 \mathrm{EUR} / 100 \mathrm{~kg}$ leads to an increase in Austrian prices by 1.41 EUR/100kg. Simultaneously, an increase in Austrian prices by $1 \mathrm{EUR} / 100 \mathrm{~kg}$ will lead to an increase in Czech prices by $0.71 \mathrm{EUR} / 100 \mathrm{~kg}$. The overall summarization of LOP testing and VEC model estimations corresponds with Figure 2. In Figure 2, a full black arrow represents relationships among countries in which LOP was confirmed. A dashed grey arrow indicates a situation where cointegration was detected, but the LOP was not confirmed at a $5 \%$ level of significance. If a country pair has both black and grey arrows, the results of LOP testing depend on the level of significance. This level is mentioned next to these arrows. Finally, the arrows also show the direction of the relationships, i.e. a one-sided effect is represented by a simple one-headed arrow $(\rightarrow)$ and a simultaneous relationship is displayed as a double-headed arrow $(\leftrightarrow)$.

As we can see in Figure 2, the LOP was confirmed for eight country pairs from ten cointegrated pairs at a $5 \%$ level of significance. If we consider a $1 \%$ level of significance, we can detect a confirmation of the LOP for ten out of ten cointegrated country pairs. For these cases, six one-sided relationships were detected. Specifically, it was found that German feed barley prices affect prices in the Czech Republic, Poland, Austria and Hungary. These markets do not have the power to influence the price of barley in Germany, i.e. Germany is the dominant market. The second most dominant market is Austria, because it has the power to influence prices in Hungary and Poland and not be influenced by these markets. A simultaneous price relationship for Austria was found only in the case of trade with the Czech Republic. Moreover, the Austrian LOP was not confirmed, twice, at a $5 \%$ level of significance. These facts support the idea that Austria is partially independent of price changes in Germany or other countries.

Countries of the original Visegrad Group (except Slovakia) have simultaneous relationships for barley prices. Therefore, Czech, Polish and Hungarian markets are closely connected to each other, and changes in one market are reflected in the others. These linkages could be 


\begin{tabular}{|c|c|c|}
\hline Country Pair & Long-run estimated relationship & Error correction coefficient $\alpha$ \\
\hline \multicolumn{3}{|c|}{ One-side price effect among country pairs } \\
\hline$C Z, D E$ & PbarleyCZ $Z_{t-1}=-1.9998+$ Pbarley $D E_{t-1}$ & $\begin{array}{l}\alpha_{\text {dPbarleyCZ }}=-0.0884[-4.2658] \\
\alpha_{\text {dPbarley } D E}=-0.0254[-0.9055]\end{array}$ \\
\hline PL, DE & PbarleyPL $L_{t-1}=1.2542+$ PbarleyDE $E_{t-1}$ & $\begin{array}{l}\alpha_{\text {dPbarleyPL }}=-0.1239[-4.6129] \\
\alpha_{\text {dPbarley } D E}=0.0073 \quad[-0.2865]\end{array}$ \\
\hline PL, AT & PbarleyPL $_{t-1}=0.2148+0.0221 t+$ PbarleyAT $_{t-1}$ & $\begin{array}{l}\alpha_{\text {dPbarleyPL }}=-0.1297[-3.7811] \\
\alpha_{\text {dPbarley } A T}=0.0286[0.6948]\end{array}$ \\
\hline AT, HU & PbarleyHU $_{t-1}=0.4369+{\text { Pbarley } A T_{t-1}}$ & $\begin{array}{l}\alpha_{d P b a r l e y H U}=-0.1561[-3.5927] \\
\alpha_{d P b a r l e y A T}=0.0338[1.5614]\end{array}$ \\
\hline $\mathrm{DE}, \mathrm{HU}$ & PbarleyHU $U_{t-1}=-0.8955+$ PbarleyDE $E_{t-1}$ & $\begin{array}{l}\alpha_{\text {dPbarleyHU }}=-0.1926[-3.7330] \\
\alpha_{d P b a r l e y D E}=0.0165 \quad[0.7458]\end{array}$ \\
\hline \multicolumn{3}{|c|}{ Simultaneous price effect among country pairs } \\
\hline $\mathrm{CZ}, \mathrm{PL}$ & PbarleyPL $_{t-1}=3.2325+$ PbarleyCZ $_{t-1}$ & $\begin{array}{l}\alpha_{\text {dPbarleyPL }}=-0.0664[-2.2218] \\
\alpha_{\text {dPbarleyCZ }}=0.0415[1.8940]^{1)}\end{array}$ \\
\hline $\mathrm{CZ}, \mathrm{HU}$ & PbarleyHU $_{t-1}=1.0483+$ PbarleyCZ $_{t-1}$ & $\begin{array}{l}\alpha_{\text {dPbarley } H U}=-0.1504[-2.3947] \\
\alpha_{\text {dPbarley } C Z}=0.0580 \quad[2.8291]\end{array}$ \\
\hline PL, HU & PbarleyPL $_{t-1}=2.1944+$ PbarleyHU $_{t-1}$ & $\begin{array}{l}\alpha_{\text {dPbarleyPL }}=-0.0765[-2.9281] \\
\alpha_{\text {dPbarleyHU }}=0.1524 \quad[2.7195]\end{array}$ \\
\hline
\end{tabular}

Note: LOP evaluated at a $5 \%$ level of significance, [ ] refers t-ratio

1) simultaneous relationship at a $10 \%$ level of significance

Source: own calculations, EViews 7

Table 8: Estimated long-run relationships for country pairs with confirmed LOP, restricted VEC models.

\begin{tabular}{|c|c|c|}
\hline $\begin{array}{c}\text { Country } \\
\text { Pair } \\
\end{array}$ & Long-run estimated relationship & Error correction factor $\alpha$ \\
\hline \multicolumn{3}{|c|}{ On-side of price effect among country pairs } \\
\hline $\mathrm{DE}, \mathrm{AT}$ & $\begin{array}{l}\text { PbarleyAT }_{t-1}=0.8081-0.0098 t+0.9060 \text { PbarleyDE }_{t-1} \\
{[\mathrm{t} \text {-stat }]}\end{array}$ & $\begin{array}{l}\alpha_{\text {dPbarleyAT }}=-0.3286[-5.8410] \\
\alpha_{\text {dPbarley } D E}=-0.0177[-0.3423]\end{array}$ \\
\hline \multicolumn{3}{|c|}{ Simultaneous price effect among country pairs } \\
\hline $\mathrm{CZ}, \mathrm{AT}$ & $\begin{array}{c}\text { Pbarley } A T_{t-1}=0.3348-0.0358 t+1.4145 \text { Pbarley } C Z_{t-1} \\
\text { [t-stat }]\end{array}$ & $\begin{array}{l}\alpha_{d P \text { barley } A T}=0.0864 \quad[2.8941] \\
\alpha_{d P \text { barley } C Z}=0.0806 \quad[4.2535]\end{array}$ \\
\hline
\end{tabular}

Note: LOP evaluated at a $5 \%$ level of significance, [ ] refers t-ratio; in both cases, LOP was rejected at a $5 \%$ level of significance, however at a $1 \%$ level we cannot reject LOP Source: own calculations, EViews 7

Table 9: Estimated long-run relationships for country pairs with unconfirmed LOP at a $5 \%$ level of significance, unrestricted VEC models.

due to long-term cooperation since 1991, as well as the fact that those countries participated in the Central European Free Trade Agreement (CEFTA) before entrance to the EU.

However, it was not confirmed that Slovakia has any price relationship with the analysed countries. The performed tests did not show any cointegration with the others. There are three possible reasons for this situation. The first reason could be that the Slovakian market does not react to prices changes in other countries for this particular commodity. This explanation is not very plausible because trade among the analysed countries is a common practise. Slovakia is also a member of regional agreements that have been made. Specifically, Slovakia is 

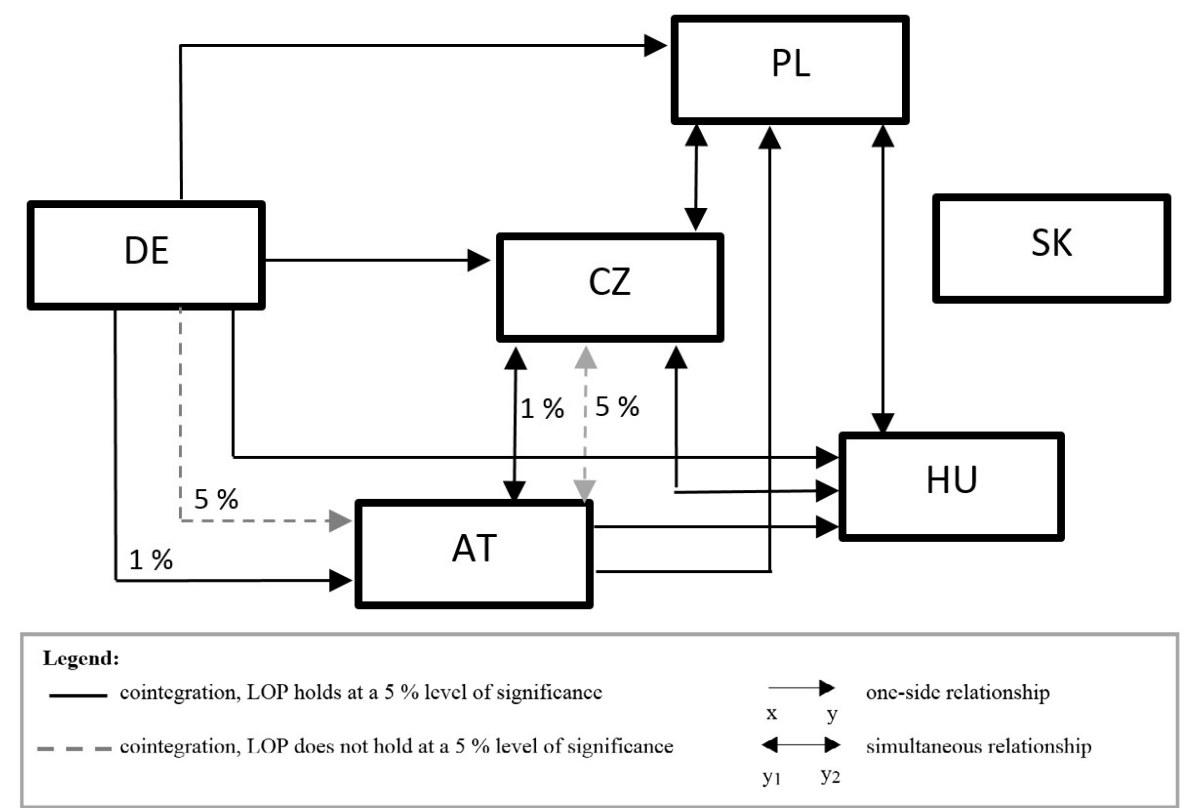

Source: Tables 7, 8 and 9

Figure 2: Price relationships among selected Central European countries, prices of barley.

currently a member of the EU along with the other investigated countries, and before entrance to the EU in 2004, the country was a member of CEFTA together with the Czech Republic, Poland and Hungary. The second reason, which is more likely to be true, is that the relationship between prices is non-linear. The VEC model analysed linear relationships and thus cointegration can be rejected despite the fact that there is some. The suggested next step in the analysis is to analyse price relations based on non-linear models, such as the Threshold autoregression model or the Threshold cointegration model. The last reason for obtaining this result of no cointegration is related to the representativeness of the Slovakian data set. There is a risk of an error occurring during the collection of data or their later publication. In conclusion, based on the performed analysis, we cannot prove the LOP or a long-run relationship of the analysed countries with Slovakia. However, we cannot reject any connections among prices, because deeper analysis must be done.

In connection with the discussion of other author's results, it is difficult to find relevant publications. The LOP of barley is not analysed frequently. The analyses of barley LOP are often out of date, such as Rogoff, Froot and Kim (2001) who analysed barley prices until the beginning of the 90 s. One recent paper was found from authors Goychuk and Mayers (2013). These authors confirmed cointegration of barley prices not just between European countries, but also among markets such as: Australia-Ukraine, UkraineFrance, Australia-Canada and Australia-France over the period 2004-2010. The LOP was confirmed for majority of country pairs. Thus the results of this paper are consistent with mentioned publication.

\section{Conclusion}

The Law of One Price for barley prices was confirmed in the majority of cases. The results of cointegration tests and VEC models show that prices of feed barley are equal over the long term among country pairs such as Czech RepublicPoland, Czech Republic-Germany, Czech RepublicHungary, Poland-Germany, Poland-Austria, Poland-Hungary, Germany-Hungary and AustriaHungary at $5 \%$ and $1 \%$ levels of significance.

The LOP does not hold between the pairs Czech Republic-Austria and Germany-Austria at a $5 \%$ level of significance. However, the hypothesis was not rejected at a $1 \%$ level of significance. The prices for these country pairs have a longterm relationship. The prices are not exactly equal to each other, but they do not differ too much.

Slovakia is the only market where prices seem to be separated from other markets. The Johansen tests did not show any cointegration with other analysed countries. There are three possible reasons for this situation - no actual long-run relationship, the existence of non-linear relationships, or a problem with the representativeness 
of the data. In general, it is not possible to confirm cointegration or LOP for Slovakian prices, but a connection among prices should not be strictly rejected. Detailed research is needed first.

Transaction costs are constant for the majority of countries. A trend behaviour for transaction costs was detected among the country pairs AustriaPoland, Austria-Czech Republic and AustriaGermany. Based on the results, we can assume that the trending costs are a feature of the Austrian market. The transaction costs of Austrian exports into Germany, the Czech Republic and Poland are increasing over time.

Evaluation of the existence of simultaneous effects suggests the following. Germany is the most dominant market, because that market influences the feed barley prices of all other countries (except Slovakia, which is not cointegrated with anything). The second most dominant market is Austria, which is also able to influence prices in Poland and Hungary. If we compare results for the two main groups of countries, namely the Visegrad group, containing the Czech Republic, Poland and Hungary, and the group of Germany and Austria, who participated in the EU much sooner than the Visegrad group, the differences are clear. Germany and Austria behave as dominant markets which influence the Visegrad group. The Visegrad group is characterized by simultaneous price relationships. The power of Germany and subsequently Austria is not just due to their earlier entrance into the EU, but rather to their economically strong position.

The frequent confirmation of the LOP shows that the market for feed barley does not suffer from barriers to international trade, and that the international market of Central European countries behaves as a free market.

\section{Acknowledgements}

This article was elaborated with the support of Grant Agency of the Czech Republic No. P402/12/G097 DYME - Dynamic Models in Economics.

Corresponding author:

Ing. Petra Bubáková, Ph.D.

Vendavo CZ, U nákladového nádraži 3147/8, Prague, 130 00, Czech Republic

E-mail:petra-bubakova@seznam.cz

\section{References}

[1] Ahmadi-Esfahani, F. Z. Testing the law of one price in the Chinese wholesale food markets. Agribusiness. 2006, Vol. 22, No.. 4, p. 569-589. ISSN 1520-6297.

[2] Akaike, H. A new look at the statistical model identification. IEEE Transactions on Automatic Control. 1974, Vol.19, No. 6, p. 716-723. ISSN 0018-9286.

[3] Bakucs, L. Z., Brummer, B., von Cramon-Taubadel, S., Imre, F. Wheat market integration between Hungary and Germany. Applied Economics Letters. 2012, Vol. 19, No. 8, p. 785-788. ISSN 1350-4851.

[4] Bubáková, P. Agricultural Prices of Pork at the Regional Level and the Law of One Price. Acta Oeconomica Pragensia. 2012, Vol.1, p. 39-51. ISSN 0572-3043.

[5] Biondo, A. E. The law of one price: survey of a failure. Theoretical and Practical Research in Economic Fields (TPREF). 2010, Vol. I, No. 2(2), p. 167-181. ISSN 2068-7710.

[6] Dickey, D., Fuller, W. Distribution of the Estimators for Autoregressive Time Series With a Unit Root. Journal of the American Statistical Association. Part 1. 1979, Vol. 74, No. 366, p. 427-431. ISSN 0162-1459.

[7] Goychuk, K., Meyers, W. H. Short-and long-run relationships between Ukrainian barley and world feed grain export prices. In 2013 Annual Meeting, February 2-5, 2013, Orlando, Florida (No. 143085). 2013. Southern Agricultural Economics Association.

[8] Hannan, E. J., Quin, G. G. The determination of the order of an autoregression. J.R. Statistic. Soc. Series. 1979, Vol.41, p. 190-195. ISSN 1467-9868. 
[9] Holman, R. Mikroekonomie: středně pokročilý kurz. 2. ed. Prague: C. H. Beck. 2007. ISBN 978-80-7179-862-0.

[10] Holman, R. Ekonomie. 5. ed. Prague: C. H. Beck. 2011. ISBN 978-80-7400-006-5.

[11] Charemza W. W., Deadman D. F. New Directions in Econometric Practice: General to Specific Modelling, Cointegration, and Vector Autoregression. $2^{\text {nd }}$ ed. Lyme: Edward Elgar. 1997, 344 p. ISBN 1-85898-603-6.

[12] Iregui, A. M., Otero, J. Testing the law of one price in food markets: evidence for Colombia using disaggregated data. Empirical Economics. 2011, Vol. 40, No. 2, p. 269-284. ISSN 0377-7332.

[13] Johansen, S. Statistical Analysis of Cointegration Vectors, Journal of Economic Dynamics and Control. 1988, Vol.12, p. 231-254. ISSN 0165-1889.

[14] Johansen, S. Estimation and Hypothesis Testing of Cointegration Vectors in Gaussian Vector Autoregressive Models, Econometrica. 1991, Vol. 59, p. 1551-80. ISSN 1468-0262.

[15] Kwiatkowski, D., Phillips, P. C. B., Schmidt, P., Shin, Y. Testing the null hypothesis of stationarity against the alternative of a unit root: How sure are we that economic time series have a unit root. Journal of Econometrics. 1992, Vol. 54, No. 1-3, p. 159-178. ISSN 0304-4076.

[16] Lajdová, Z., Bielik P. The evidence of asymmetric price adjustments. Agriculture Economics. 2015, Vol. 61, No. 3, p. 105-115. ISSN 0139-570X.

[17] Phillips, P. C. B., Perron, P. Testing for a Unit Root in Time Series Regression. Biometrika. 1988, Vol. 75, p. 335-346. ISSN 0006-3444.

[18] Rogoff, K., Froot, K., Kim, M. The law of one price over 700 years. 2001. Working paper No. 174. International Monetary Fund. $42 \mathrm{~s}$.

[19] Spreen, T. H., Kilmer, R. L., Pitta, C. R. Nonhomogeneous products and the law of one price. Agribusiness. 2007, Vol. 23, No. 3, p. 407-420. ISSN 1520-6297.

[20] Schwarz, G. Estimating the dimension of a model. Annals of Statistics. 1978, Vol. 6, No. 2, p. 461-464. ISSN 0090-5364.

[21] Smutka, L., Steininger, M., Maitah, M., Rosochatecká, E., Belova, A., Nassir, S. Retail food prices in the Czech Republic - the influence of selected factors. Acta univ. agric. et sil-vic. Mendel. Brun. 2013, Vol. LXI, No. 2, p. 481-492. ISSN 1211-8516.

[22] Syrovátka, P. Analysis of price interactions between Czech and world wheat markets. Acta univ. agric. et sil-vic. Mendel. Brun. 2010, Vol. LVIII, No. 6, p. 533-542. ISSN 1211-8516.

[23] Vataja, J. Should the Law of One Price Be Pushed Away? Evidence from International Commodity Markets. Open Economies Review. 2000, Vol. 11, No. 4, p. 399-415. ISSN 0923-7992.

[24] Vavra, P., Goodwin, B. K. Analysis of Price Transmission Along the Food Chain. OECD Food, Agriculture and Fisheries Working Papers, No. 3, OECD Publishing. 2005. ISSN 1815-6797.

\section{Appendix}

\begin{tabular}{|c|c|c|c|c|c|c|c|c|}
\hline $\begin{array}{c}\text { Country } \\
\text { Pair }\end{array}$ & Final Lag* & $\begin{array}{c}\text { Information criterion } \\
\text { dermining particular } \\
\text { lag }\end{array}$ & $\begin{array}{c}\text { Country } \\
\text { Pair }\end{array}$ & Final Lag** & $\begin{array}{c}\text { Information criterion } \\
\text { dermining particular } \\
\text { lag }\end{array}$ & $\begin{array}{c}\text { Country } \\
\text { Pair }\end{array}$ & $\begin{array}{c}\text { Final Lag* } \\
\text { Latermining particular } \\
\text { lag }\end{array}$ \\
\hline CZ, SK & 2 & SIC, AIC, H-Q & SK, PL & 4 & SIC, H-Q & PL, AT & 8 & AIC \\
\hline CZ, PL & 6 & AIC & SK, DE & 3 & AIC & PL, HU & 4 & AIC \\
\hline CZ, DE & 3 & H-Q & SK, AT & 5 & AIC & DE, AT & 2 & AIC \\
\hline CZ, AT & 5 & H-Q & SK, HU & 4 & AIC & DE, HU & 5 & AIC \\
\hline CZ, HU & 3 & AIC, H-Q & PL, DE & 5 & H-Q & AT, HU & 2 & AIC, H-Q \\
\hline
\end{tabular}

Note: *lag with best results of autocorrelation testing

Shortcuts: AT = Austria, CZ = Czech Republic, DE = Germany, HU = Hungary, $\mathrm{PL}=$ Poland, $\mathrm{SK}=\mathrm{Slovakia}$

Source: own calculations, EViews 7

Figure A1: Determination of lag for Johansen test, information criteria and testing of autocorrelation of VAR model . 


\begin{tabular}{|c|c|c|c|c|c|c|c|c|c|}
\hline Specification of the model: & \multicolumn{3}{|c|}{ Type 1} & \multicolumn{3}{|c|}{ Type 2} & \multicolumn{3}{|c|}{ Type 3} \\
\hline \multicolumn{10}{|c|}{$\mathrm{CZ}, \mathrm{PL}$} \\
\hline $\mathrm{H}_{0}$ : Num. of coint. vectors & Trace stat. & P-value & Result & Trace stat. & P-value & Result & Trace stat. & P-value & Result \\
\hline None & 26.107 & 0.007 & 1 cointeg. vector & 25.652 & 0.001 & 2 cointeg. vectors & 37.71 & 0.001 & 2 cointeg. vectors \\
\hline At most 1 & 7.959 & 0.084 & & 7.871 & 0.005 & & 13.848 & 0.03 & \\
\hline \multicolumn{10}{|c|}{$\mathrm{CZ}, \mathrm{DE}$} \\
\hline $\mathrm{H}_{0}$ : Num. of coint. vectors & Trace stat. & P-value & Result & Trace stat. & P-value & Result & Trace stat. & P-value & Result \\
\hline None & 22.924 & 0.021 & 1 cointeg. vector & 22.312 & 0.004 & 2 cointeg. vectors & 35.463 & 0.002 & 2 cointeg. vectors \\
\hline At most 1 & 4.597 & 0.331 & & 4.396 & 0.036 & & 13.212 & 0.038 & \\
\hline \multicolumn{10}{|c|}{$\mathrm{CZ}, \mathrm{AT}$} \\
\hline $\mathrm{H}_{0}:$ Num. of coint. vectors & Trace stat. & P-value & Result & Trace stat. & P-value & Result & Trace stat. & P-value & Result \\
\hline None & 13.722 & 0.309 & 0 cointeg. vectors & 12.914 & 0.118 & 0 cointeg. vectors & 26.948 & 0.037 & 1 cointeg. vector \\
\hline At most 1 & 4.501 & 0.343 & & 4.274 & 0.039 & & 7.315 & 0.313 & \\
\hline \multicolumn{10}{|c|}{$\mathrm{CZ}, \mathrm{HU}$} \\
\hline $\mathrm{H}_{0}:$ Num. of coint. vectors & Trace stat. & P-value & Result & Trace stat. & P-value & Result & Trace stat. & P-value & Result \\
\hline None & 26.122 & 0.007 & 1 cointeg. vector & 25.522 & 0.001 & 2 cointeg. vectors & 32.141 & 0.007 & 1 cointeg. vector \\
\hline At most 1 & 6.531 & 0.154 & & 5.941 & 0.015 & & 12.323 & 0.054 & \\
\hline \multicolumn{10}{|c|}{ PL, DE } \\
\hline $\mathrm{H}_{0}$ : Num. of coint. vectors & Trace stat. & P-value & Result & Trace stat. & P-value & Result & Trace stat. & P-value & Result \\
\hline None & 29.348 & 0.002 & 1 cointeg. vector & 28.912 & 0.000 & 2 cointeg. vectors & 36.078 & 0.002 & 1 cointeg. vector \\
\hline At most 1 & 4.591 & 0.331 & & 4.155 & 0.042 & & 10.306 & 0.114 & \\
\hline \multicolumn{10}{|c|}{ PL, AT } \\
\hline $\mathrm{H}_{0}:$ Num. of coint. vectors & Trace stat. & P-value & Result & Trace stat. & P-value & Result & Trace stat. & P-value & Result \\
\hline None & 19.764 & 0.058 & 0 cointeg. vector & 19.357 & 0.012 & 2 cointeg. vector & 29.565 & 0.017 & 1 cointeg. vector \\
\hline At most 1 & 7.002 & 0.126 & & 6.782 & 0.009 & & 12.507 & 0.050 & \\
\hline \multicolumn{10}{|c|}{ PL, HU } \\
\hline $\mathrm{H}_{0}$ : Num. of coint. vectors & Trace stat. & P-value & Result & Trace stat. & P-value & Result & Trace stat. & P-value & Result \\
\hline None & 25.248 & 0.009 & 1 cointeg. vector & 24.740 & 0.002 & 2 cointeg. vectors & 31.261 & 0.010 & 1 cointeg. vector \\
\hline At most 1 & 6.296 & 0.169 & & 5.853 & 0.016 & & 11.830 & 0.065 & \\
\hline \multicolumn{10}{|c|}{ DE, AT } \\
\hline $\mathrm{H}_{0}:$ Num. of coint. vectors & Trace stat. & P-value & Result & Trace stat. & P-value & Result & Trace stat. & P-value & Result \\
\hline None & 31.914 & 0.001 & 1 cointeg. vector & 31.384 & 0.000 & 1 cointeg. vector & 47.489 & 0.000 & 1 cointeg. vector \\
\hline At most 1 & 3.208 & 0.543 & & 2.792 & 0.095 & & 6.679 & 0.379 & \\
\hline \multicolumn{10}{|c|}{ DE, $\mathrm{HU}$} \\
\hline $\mathrm{H}_{0}$ : Num. of coint. vectors & Trace stat. & P-value & Result & Trace stat. & P-value & Result & Trace stat. & P-value & Result \\
\hline None & 20.623 & 0.045 & 1 cointeg. vector & 20.052 & 0.010 & 2 cointeg. vector & 26.508 & 0.042 & 1 cointeg. vector \\
\hline At most 1 & 5.127 & 0.270 & & 4.731 & 0.030 & & 10.949 & 0.090 & \\
\hline \multicolumn{10}{|c|}{ AT, $\mathrm{HU}$} \\
\hline $\mathrm{H}_{0}:$ Num. of coint. vectors & Trace stat. & P-value & Result & Trace stat. & P-value & Result & Trace stat. & P-value & Result \\
\hline None & 21.275 & 0.036 & 1 cointeg. vector & 20.397 & 0.008 & 1 cointeg. vector & 26.158 & 0.046 & 1 cointeg. vector \\
\hline At most 1 & 1.670 & 0.842 & & 0.875 & 0.349 & & 3.700 & 0.785 & \\
\hline
\end{tabular}

Note: Evaluation at a $5 \%$ level of significance. Results for Slovakia were shown in Table 5;

Shortcuts: $\mathrm{AT}=$ Austria, $\mathrm{CZ}=$ Czech Republic, $\mathrm{DE}=$ Germany, $\mathrm{HU}=$ Hungary, $\mathrm{PL}=$ Poland, $\mathrm{SK}=$ Slovakia

Source: own calculations, EViews 7

Figure A2: Results of Johansen test for particular specifications of VEC models and country pairs. 